\title{
Evaluation of antioxidant, anti-hemolytic and anticancer activity of various solvent extracts of Acacia hydaspica R. Parker aerial parts
}

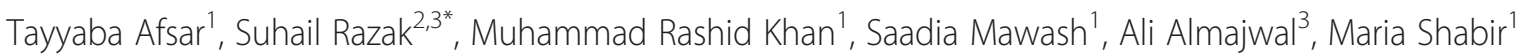
and Ihsan UI Haq ${ }^{4}$

\begin{abstract}
Background: Acacia hydaspica R. Parker, family leguminosae, is a medicinally important plant. Different plant parts are used in various ailments in folk medicine. The current study aimed at investigating the in vitro antioxidant, anti-hemolytic and anticancer activity of A. hydaspica.

Methods: Antioxidant potential was assessed using DPPH, ABTS and $\cdot \mathrm{OH}$, scavenging of $\mathrm{H}_{2} \mathrm{O}_{2}$, inhibition of lipid peroxidation and $\beta$-carotene bleaching inhibition assays. Anti-hemolytic activity was assessed $u$ sing $\mathrm{H}_{2} \mathrm{O}_{2}$ induced hemolysis of RBCs. Anticancer potential was assessed using MTT assay. Spectrometric methods and HPLC-DAD analysis was performed for phytochemical screening.

Results: $\mathrm{EC}_{50}$ values based on reduction of DPPH, ABTS and $\cdot \mathrm{OH}$, scavenging of $\mathrm{H}_{2} \mathrm{O}_{2}$, inhibition of lipid peroxidation and $\beta$-carotene bleaching for $A H B, A H E$ and $A H M$ were generally lower manifesting potential antiradical capacities. The fractions also exhibited significant $(P<0.001)$ anti-hemolytic potential. Regarding $I_{50}$ values for anticancer activity against HCC-38 and MDA-MB-361 cancer cell lines; AHB, AHE and AHM exhibited significant $(P<0.001)$ cyto-selection indices. Plant extracts showed no cytotoxicity against normal Vero cells $\left(\mid C_{50}>250 \mu \mathrm{g} / \mathrm{ml}\right)$. While significant $(P<0.001)$ cytotoxicity was elicited by these extract/fractions against cancer cell lines. AHE was the most effective and $I_{50}$ was found to be $29.9 \pm 0.909 \mu \mathrm{g} / \mathrm{ml}(\mathrm{SI}=9.83)$ and $39.5 \pm 0.872 \mu \mathrm{g} / \mathrm{ml}(\mathrm{SI}=7.44)$ against MDA-MB-361 and HCC-38 cancer cells respectively. Higher amounts of TPC and TFC were exhibited by AHE and AHB as compared to other fractions. Gallic acid, catechin and myricetin were identified in AHE whereas gallic acid and catechin were identified in AHB by HPLC.
\end{abstract}

Conclusion: The presence of bioactive constituents in AHE and AHB might be responsible for antioxidant, anti-hemolytic and anticancer activities.

Keywords: Cytotoxic activity, Antioxidant activity, Phenolic, Flavonoids, Anti-lipid peroxidation

\footnotetext{
*Correspondence: ruhail12345@yahoo.com

2Department of Animal Sciences, Faculty of Biological Sciences, Quaid-i-Azam

University, Islamabad, Pakistan

${ }^{3}$ Department of Community Health Sciences, College of Applied Medical

Sciences, King Saud University, Riyadh, Kingdom of Saudi Arabia

Full list of author information is available at the end of the article
} 


\section{Background}

Cancer is a prominent reason of death in many developed and developing countries. Although the etiologies of cancer are varied, oxidative stress plays a major role for the pathophysiological developments. Oxidative stress forced by free radicals such as singlet oxygen species, superoxide, hydroxyl and ferrous may cause lipid peroxidation, protein damages, inflammation, autoimmune pathologies, DNA damage, altering cellsignaling pathways and modulating gene expression, induction and promotion of tumor [1, 2]. Synthetic antioxidants, such as butylated hydroxyanisole (BHA) and butylated hydroxytoluene (BHT) are widely used in the food industry because they are effective and less expensive than natural antioxidants. Synthetic antioxidants gained safety concerns and have been restricted due to their DNA damaging and other toxic effects [3]. Complementary and alternative medicine is one of the emerging fields in health care today, especially as supportive medicine in treating diseases like cancer [4]. Plant secondary metabolites such as flavonoids, terpenes, alkaloids, $\alpha$-tocopherol and carotenoids have received considerable attention in recent years due to their diverse pharmacological properties, including cytotoxic and chemo-preventive effects. The possible health benefits of polyphenol consumption have been suggested to derive from their antioxidant properties $[4,5]$. Therefore it is interesting to identify selectivity of plant extracts possessing antioxidant potential against cancer and normal cells. In fact, literature has verified an association between intake of diet rich in fruits and vegetables with a decline in oxidative stress induced disorders [6].

Acacia hydaspica R. Parker synonym A. eburnea, commonly known as 'kikar' family leguminosae is an economically important plant. It is a slender deciduous shrub, 1.2-1.8 m tall, twigs glabrous slightly zigzag; bark smooth, dark grey and 1.2-2.5 cm long stipular spines, seeds 1-8, areole not well marked. The bark and seeds are the source of tannin. Leaves serves as fodder for goats $[7,8]$. The bark and seeds are the source of tannins. The plant is locally used as antiseptic. The traditional healers of India use various parts of the plant for the treatment of diarrhea; the leaves and the bark are useful in arresting secretion or bleeding. The pods are helpful in removing catarrhal matter and phlegm from the bronchial tubes. The gum dispels irascibility of the skin and soothes the inflamed membranes of the pharynx, alimentary canal and genito-urinary organs (http://trade.indiamart.com/ details.mp?offer=6763150691). Gallic acid, catechin, rutin and caffeic acid have been identified in A. hydaspica by HPLC-DAD screening of crude methanol extract, while 7$O$-galloyl catechin, +catechin and methyl gallate have been isolated from ethyl acetate fraction of $A$. hydaspica (AHE).
The A. hydaspica possess anti-inflammatory, antipyretic and analgesic potentials [9]. Polyphenolic compounds isolated from $A$. hydaspica induce apoptosis and inhibit cancer cell growth in vitro in breast and prostate cancer cells by modulating various signal transduction pathways [10]. Various species of Acacia were investigated for their antioxidant and anticancer potentials in various animal models [11]. The extracts from the bark and heartwood of Acacia confusa showed significant antioxidant activity in various antioxidant assays, including free radical and superoxide radical scavenging assays and lipid peroxidation assay as well as hydroxyl radical-induced DNA strand scission assay [12]. A. mangium and A. auriculiformis heartwood extracts showed excellent quenching ability against DPPH free radicles [13]. The antioxidant activities of bark extract of Acacia confusa and some of the isolated constituents from its ethyl acetate (EtOAc) fraction in various in vitro systems together with authentic antioxidant standards revealed that EtOAc fraction showed strong superoxide radical scavenging activity, reducing power, and ferrous ion-chelating ability. Results obtained indicated that the bark extracts from $A$. confusa have a great potential to prevent disease caused by the overproduction of radicals and also it might be used as a potential source of natural antioxidant agent [14]. Heartwood extract of Acacia catechu induces apoptosis in human breast cancer cell [15]. However to the best of our knowledge there is no single scientific report demonstrating the antioxidant and cyto-selective anticancer potential of $A$. hydaspica.

In this study qualitative phytochemical screening, total phenolic content (TPC), total flavonoid content (TFC), antioxidant and anti-hemolytic activities of extract/fractions were evaluated. Extracts with potent antioxidant activity were tested against normal (VERO) and cancer cell lines (HCC-38 and MDA-MB-361) in order to evaluate the cyto-selective potential against cancer and normal cells. Furthermore polyphenol constituents in active fractions were determined by HPLC-DAD chromatography using standard reference compounds.

\section{Methods \\ Plant collection}

The plant was collected from Kirpa village Islamabad, Pakistan. After identification with the help of relevant literature a voucher specimen was deposited (0642531) at the Herbarium of Pakistan Museum of Natural History, Islamabad.

\section{Preparation of extract/fractions}

The aerial parts (twigs and leaves) of the plant were dried in an aerated but shaded area. Dried material was ground by an electrical grinder to obtain $60 \mu \mathrm{m}$ powder. The methanol extract was obtained by allowing $3 \mathrm{~kg}$ of 
powder to macerate three times in $95 \%$ methanol $(3 \times$ $4000 \mathrm{ml}$ ) for five consecutive days. The supernatants were mixed and filtered. Solvent was evaporated by rotary vacuum evaporator (Buchi, R114, Switzerland). The residue was taken to dryness to obtain a viscous mass as the crude methanol extract (AHM). An amount of $12 \mathrm{~g}$ of AHM was suspended in water $(250 \mathrm{ml})$ with continuous stirring then successively added $(3 \times 200 \mathrm{ml})$ following solvents; $n$-hexane, ethyl acetate, chloroform and $n$-butanol respectively, shake well and each layer was allowed to separate for $3 \mathrm{~h}$ in a separating funnel and at last water soluble fraction was obtained (AHA). Each of the fractions obtained were dried using a rotary evaporator. AHM and its five subsequent fractions: $\mathrm{AHH}, \mathrm{AHE}, \mathrm{AHC}, \mathrm{AHB}$ and AHA were weighed and expressed in terms of percentage of air dried weight of plant material.

\section{Chemicals}

Ascorbic acid, aluminum chloride, 2,2-azino-bis-(3ethylbenzothiazoline-6-sulphonic acid) (ABTS), ferric chloride $\left(\mathrm{FeCl}_{3}\right)$, Tween 80, $\beta$-carotene, (+)-catechin, gallic acid, rutin, quercitin, potassium persulphate, Folin-Ciocalteu's reagent, ferrozine, gallic acid, rutin, linoleic acid, 2,2-diphenyl-1-picrylhydrazyl (DPPH), nitro blue tetrazolium (NBT), linoleic acid, phenazine methosulphate (PMS), thiobarbituric acid (TBA) and trichloroacetic acid (TCA) were purchased from Sigma Aldrich (Germany). Deoxyribose, riboflavin, sodium carbonate $\left(\mathrm{Na}_{2} \mathrm{CO}_{3}\right)$, sodium hydroxide $(\mathrm{NaOH})$, disodium hydrogen phosphate $\left(\mathrm{Na}_{2} \mathrm{HPO}_{4}\right)$ and hydrogen peroxide $\left(\mathrm{H}_{2} \mathrm{O}_{2}\right)$ were obtained from Wako Co. (Osaka, Japan). Potassium ferricyanide $\left(\mathrm{K}_{3} \mathrm{Fe}(\mathrm{CN})_{6}\right)$, triflouroacetic acid, sodium dihydrogen phosphate $\left(\mathrm{NaH}_{2} \mathrm{PO}_{4}\right)$ and all solvents used were of analytical grade and were purchased from Sigma Aldrich (Germany).

\section{Preliminary phytochemical screening}

The methanol extract and its soluble fractions were subjected to phytochemical analysis by using the methods described previously for the detection of terpenoids, alkaloids [16], saponins, tannins, flavonoids [17], cardiac glycoside [18], reducing sugars [19], pholobatannins, coumarins and anthraquinones [20] by qualitative methods.

\section{Estimation of total phenolic content (TPC)}

The total phenols of AHM and its derived fractions were quantified by previously described spectrophotometric method [21]. TPC was calculated from the calibration curve of gallic acid. Estimation of TPC was recorded in triplicate and expressed as mg of gallic acid equivalent/g of dry sample.

\section{Estimation of total flavonoid content (TFC)}

Aluminium chloride colorimetric technique with slight modifications was used for the estimation of TFC [22]. Quantity of TFC was recorded in triplicate from the calibration curve of rutin and expressed as $\mathrm{mg}$ of rutin equivalent/g of dry sample.

\section{Antioxidant assays \\ Sample preparation}

Each sample was dissolved in $95 \%$ methanol at a concentration of $1 \mathrm{mg} / \mathrm{ml}$ and diluted to prepare the serialized dilutions $(10-500 \mu \mathrm{g} / \mathrm{ml})$ for various antioxidant assays. Reference standard chemicals were used for comparison in all assays.

\section{Antioxidant activity assessment assays $D P P H$ radical scavenging activity assay}

The DPPH assay was executed following previously established protocol with slight modifications [23]. One hundred milliliter methanol (80\%) was added to $24 \mathrm{mg}$ of DPPH to make the stock solution and the stock was stored at $20{ }^{\circ} \mathrm{C}$ till used. For the assay the working solution of DPPH was prepared by diluting the stock with methanol until an absorbance of $0.751 \pm 0.02$ at $517 \mathrm{~nm}$ was achieved. An aliquot of $1 \mathrm{ml} \mathrm{DPPH}$ solution was dispensed in $100 \mu \mathrm{l}$ of the test samples of different concentrations $(0-250 \mu \mathrm{g} / \mathrm{ml})$. The mixture was shaken and placed in the dark for $10 \mathrm{~min}$ at room temperature. The absorbance of the mixture was recorded using a UV1601 spectrophotometer (Shimadzu, Kyoto, Japan) at $517 \mathrm{~nm}$. The decrease in absorbance was correlated with the radical scavenging potential of test samples. The percentage of inhibition was assessed as follow

$$
\% \text { DPPH scavenging }=\left[\frac{\text { Ad- }-(\text { Asd-Asa })}{\text { Ad }}\right] \times 100 \text {. }
$$

Where Ad is the DPPH solution absorbance, Asd is the absorbance of solution containing test sample and DPPH solution, and Asa is the absorbance sample solution without DPPH. Each sample was analyzed in thrice.

As a standard reference compound ascorbic acid was employed.

\section{Superoxide anion radical quenching assay}

Quenching potential for superoxide anion was assessed via riboflavin light-NBT system [24]. $1 \mathrm{ml}$ sample solution $(25-250 \mu \mathrm{g} / \mathrm{ml})$ was poured to the solution comprised of $50 \mathrm{mM}$ phosphate buffer (500 $\mu \mathrm{l}, \mathrm{pH} 7.6)$, $50 \mathrm{mM}$ riboflavin $(300 \mu \mathrm{l}), 20 \mathrm{mM}$ PMS $(250 \mu \mathrm{l})$ and $0.5 \mathrm{mM}$ NBT $(100 \mu \mathrm{l})$. Illumination of the solution was done by using a fluorescent lamp for initiating the reaction. The absorbance of samples was recorded at $560 \mathrm{~nm}$ after $20 \mathrm{~min}$ of illumination. Restraint of 
superoxide anion liberation was assessed using the following formula:

$$
\text { Inhibitory potentieal }(\%)=\left[\frac{\text { Control abs-sample abs }}{\text { control abs }}\right] \times 100
$$

Gallic acid was used as a standard compound.

\section{Hydroxyl radical quenching activity}

Scavenging potential of test samples for the hydroxyl radicals was examined using 2-deoxyribose method [25]. 0.2 M Phosphate buffer saline (PH 7.4) was consumed as a solvent in this test. Sample solution $(0-100 \mu \mathrm{M})$ was mixed with test mixture containing 2-deoxyribose (2.8 $\mathrm{mM})$, ferrous ammonium sulphate solution (20 mM), EDTA $(100 \mu \mathrm{M})$. Total volume of test mixture was made up to $1 \mathrm{ml}$ with $0.2 \mathrm{M}$ Phosphate buffer saline (PH 7.4). Ferrous ion solution and EDTA were premixed before adding to the assay mixture. The reaction was

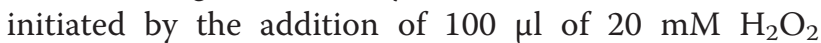
and $100 \mu \mathrm{l}$ of $2 \mathrm{mM}$ ascorbic acid and incubated at $37{ }^{\circ} \mathrm{C}$ for $15 \mathrm{~min}$. Then, thiobarbituric acid solution (1 $\mathrm{ml}, 1 \%, w / v)$ and trichloroacetic acid solution ( $1 \mathrm{ml}, 2 \%, w / v)$ were added. The mixture was boiled in water bath for $15 \mathrm{~min}$ and cooled in ice, and its absorbance was measured at $532 \mathrm{~nm}$. All experiments involving these samples were triplicated. The scavenging activity were calculated by following formula.

Radical quenching capacity $(\%)$

$$
=\left[\frac{\text { Control absorbance-sample absorbance }}{\text { control absorbance }}\right] \times 100
$$

Gallic acid was employed as a reference standard.

\section{Hydrogen peroxide radical quenching assay}

Hydrogen peroxide solution (200 $\mathrm{mM}$ ) was prepared in phosphate buffer (50 mM, pH 7.4). $100 \mu \mathrm{l}$ of test sample $(0.1-0.5 \mathrm{mg} / \mathrm{ml})$ mixed with $400 \mu \mathrm{l}$ of $50 \mathrm{mM}$ phosphate buffer ( $\mathrm{pH} 7.4$ ), then add $600 \mu \mathrm{l}$ hydrogen peroxide solution and vortex the sample tubes. Note the absorbance of the solution at $230 \mathrm{~nm}$ after $10 \mathrm{~min}$ against a blank [26].

Hydrogen peroxide scavenging ability is estimated as follow:

$$
\text { Quenching capacity }(\%)=\left[\frac{\text { Control abs-sample abs }}{\text { Control abs }}\right] \times 100
$$

Ascorbic acid was used as a standard reference.

\section{ABTS radical scavenging activity}

ABTS test was employed to evaluate the antioxidant prospective of biological fluids, tissues, natural and synthetic complexes. The $\mathrm{ABTS}^{+}$radical cation formation induced by metmyoglobin and hydrogen peroxide is measured by previously establish protocol [27]. ABTS (7 $\mathrm{mM}$ ) was allowed to react in dark with potassium persulfate $(2.45 \mathrm{mM})$ for $12 \mathrm{~h}$ to get a dark shaded ABTS radical cations solution. The ABTS solution used for the assay was prepared by diluting it with methanol (50\%) to achieve an absorbance of around 0.70 at $745 \mathrm{~nm}$. ABTS radical quenching potential was judged by adding $1.0 \mathrm{ml}$ of ABTS working solution in $100 \mu \mathrm{l}$ of test sample. The drop in absorbance was recorded precisely after one minute, then at 3rd min and last reading recorded at 6 th $\mathrm{min}$. The following formula was applied to calculate percentage inhibition:

$$
\text { Quenching ability }(\%)=\left[\frac{\text { Control abs-sample abs }}{\text { control abs }}\right] \times 100
$$

Ascorbic acid was used as a standard control.

\section{Iron chelating power}

The extract potency to chelate iron (II) was estimated by previous described procedure [26]. Two hundred microliter each sample $(50-250 \mu \mathrm{g} / \mathrm{ml})$ was mixed with $0.1 \mathrm{ml}$ of $\mathrm{FeCl}_{2} .2 \mathrm{H}_{2} \mathrm{O}(2.0 \mathrm{mM})$ and $0.9 \mathrm{ml}$ of $\mathrm{MeOH}$. The reaction was started by the addition of $0.4 \mathrm{ml}$ of ferrozine (5.0 $\mathrm{mM}$ ) after $5 \mathrm{~min}$ of incubation. The absorbance of the solution was noted at $562 \mathrm{~nm}$ after incubation of $10 \mathrm{~min}$. The percent chelating potential (\%) was assessed by employing the following equation:

$$
\text { Chelating action }(\%)=\left[\frac{\text { Control abs-sample abs }}{\text { Control abs }}\right] \times 100
$$

Catechin was used as a reference compound.

\section{$\beta$ - carotene bleaching test}

The test was accomplished as per previously described protocol with slight modifications [28]. Twenty-five microliter of linoleic acid and $400 \mu \mathrm{l}$ of Tween 80 were poured in $500 \mu \mathrm{g}$ of $\beta$-carotene (dissolved in $1 \mathrm{ml}$ of chloroform). Next step was the removal of chloroform under vacuum. After evaporation of chloroform $100 \mathrm{ml}$ of distilled water was added to the residue and shaken well to make $\beta$-carotene linoleate suspension. $1 \mathrm{ml}$ of suspension was mixed with test sample $(0.1 \mathrm{ml})$ and the absorbance of the mixture was noted instantaneously against the blank at $470 \mathrm{~nm}$. Next the samples were positioned for $2 \mathrm{~h}$ in water bath set at $45{ }^{\circ} \mathrm{C}$. Subsequently the absorbance is recorded again at $470 \mathrm{~nm}$. The antioxidant potency was assessed as percent impediment of oxidation by employing the subsequent equation.

$$
\text { Bleaching inhibition }(\%)=\left[1-\frac{\mathrm{At} 0-\mathrm{At} 120}{\mathrm{Ac} 0-\mathrm{Ac} 120}\right] \times 100
$$

At0 is the initial absorbance

At120 is the absorbance of solution after $120 \mathrm{~min}$ 
Catechin and BHT were employed as a standard reference.

\section{Anti-lipid peroxidation analysis}

This test was performed in accord with scheme described earlier [29]. The extract/fractions were dissolved in methanol to prepare varying concentrations of sample solutions $(50-1000 \mu \mathrm{g} / \mathrm{ml})$. An aliquot of $300 \mu \mathrm{l}$ of $\mathrm{CuCl}_{2}$ solution $(0.05 \mathrm{mM})$ was added to each test tube before adding sample $(50 \mu \mathrm{l})$ and linoleic acid $(100 \mu \mathrm{l})$. Mixture was vortexes for $5 \mathrm{~s}$ and kept for $20 \mathrm{~h}$ for incubation in shaking water bath set at $37^{\circ} \mathrm{C}$. Twenty microliter of BHT (prepared in $10 \mathrm{mM}$ in ethanol) was poured to each test tube to stop the reaction. Solution of TBA was prepared by dissolving $0.67 \%$ TBA in $0.1 \mathrm{M} \mathrm{HCl}$ by sonication and momentary heating. Afterward, $3 \mathrm{ml}$ of this freshly prepared solution of TBA (thiobarbituric acid) was added to each sample tube and mixture was vortexed for $5 \mathrm{~s}$. The sample tubes were kept in hot water bath for $10 \mathrm{~min}$. After cooling the sample tubes, the pink aqueous layer was transferred to new test tubes containing $2.5 \mathrm{ml}$ of $100 \% n$-butanol. Mixture was vortexed for $5 \mathrm{~s}$ and allowed to settle. Absorbance of pink solution was noticed at $532 \mathrm{~nm}$ using spectrophotometer.

Percentage inhibition was measured according to following formula:

Lipid peroxidation impediment (\%)

$$
=\left[\frac{\text { Control absorbance-sample absorbance }}{\text { control absorbance }}\right] \times 100
$$

BHA was used as a reference standard.

Total antioxidant capacity (TAC) (Phosphomolybdate assay) Phosphomolybdate method was used to determine the antioxidant capacity of compounds [30]. One thousand microliter of assay mixture comprising $\mathrm{H}_{2} \mathrm{SO}_{4}(0.6 \mathrm{M})$, sodium phosphate $(0.028 \mathrm{M})$ and ammonium molybdate $(0.004 \mathrm{M})$ was poured to the sample tubes containing $100 \mu \mathrm{l}$ of test sample. Incubation of mixture was done for $90 \mathrm{~min}$ in hot water bath set at $95{ }^{\circ} \mathrm{C}$. The absorbance of reaction mixture was noted at $765 \mathrm{~nm}$ after the samples were cooled.

Ascorbic acid employed as reference standard.

\section{Reducing power assay}

The protocol of Kumaran was followed for assessing the reducing ability of the extract/fractions [31]. An amount of $0.5 \mathrm{ml}$ of phosphate buffer $(0.2 \mathrm{M}, \mathrm{pH} 6.6)$ and $0.5 \mathrm{ml}$ of potassium ferricyanide was mixed with $0.5 \mathrm{ml}$ of the extract/fractions $(50-250 \mu \mathrm{g} / \mathrm{ml})$ and incubated at $50{ }^{\circ} \mathrm{C}$ for duration of $20 \mathrm{~min} .10 \%$ TCA solution $(0.5 \mathrm{ml})$ was added to the reaction mixture in order to stop the reaction. Afterwards, $0.5 \mathrm{ml}$ solution was pipetted out from each reaction mixture tube and permitted to mix with ferric chloride $(100 \mu \mathrm{l})$ and of distilled water $(0.5 \mathrm{ml})$. Optical density of the chromogen made was note down at $700 \mathrm{~nm}$ after incubation of sample for $10 \mathrm{~min}$. Higher absorbance values were proportionated to higher reducing potency.

Values obtained for gallic acid were used as reference standard.

\section{Anti-hemolytic activity}

Anti-hemolytic potential of extract/fractions was inspected by spectrophotometric procedure as described previously [32]. Five milliliter of blood from a healthy person was collected in EDTA vials and centrifuged for 5 min at $1000 \times$ g. Supernatant was removed and pellet was washed thrice with PBS $(0.2 \mathrm{M}, \mathrm{pH} 7.4)$ before re-suspending in saline solution (0.5\%). $0.5 \mathrm{ml}$ of the extract/fractions (100$1000 \mu \mathrm{g} / \mathrm{ml}$ in PBS) was dispensed to $1 \mathrm{ml}$ of erythrocyte suspension and incubated at room temperature for $20 \mathrm{~min}$. Next add $0.5 \mathrm{ml}$ of $\mathrm{H}_{2} \mathrm{O}_{2}$ solution made in buffered saline to the reaction mixture for provoking oxidative degradation of the membrane lipids. Subsequently, the samples were centrifuged at $1000 \times \mathrm{g}$ for $10 \mathrm{~min}$ and the absorbance of supernatant was noted spectrophotometrically at $540 \mathrm{~nm}$. The relative hemolysis was assessed in comparison with the hemolysis in the $\mathrm{H}_{2} \mathrm{O}_{2}$ treated (negative control), which was set as $100 \%$. For positive control phosphate buffer saline was used. Each set of experiments was performed in triplicate and inhibitory activity of different fractions was calculated and expressed as percent inhibition of hemolysis. Quercetin $(100-500 \mu \mathrm{g} / \mathrm{ml})$ treated in the similar manner was employed as a reference compound. The study protocol was in agreement with Helsinki Declaration. Study approval (Bch\#0256) was obtained from the Ethical Review Committee, Quaid-i-Azam University. Islamabad. Informed consent was obtained from persons who participated in the study.

\section{Cytotoxicity screening \\ Cell lines and cell culture}

HCC-38 (CRL-2314 ${ }^{\mathrm{m}}$, homosapien, mammary carcinoma epithelial cells, estrogen receptor negative), MDA-MB361 (HTB-27 ${ }^{\text {tum }}$, homosapien, mammary gland/breast; derived from metastatic site: brain) and Vero (CCL- $81^{\mathrm{m}}$, normal kidney cells) cell lines were obtained from ATCC (Manassas, VA, USA). MDA-MB-361 and HCC-38 cells were routinely cultured in DMEM/F12, whereas Vero cells were grown in MEM media (Invitrogen), supplemented with $10 \%$ FBS (Invitrogen 16000-044) and $1 \%$ Penicillin/Streptomycin (Invitrogen 15140-122). The cells were incubated at $37{ }^{\circ} \mathrm{C}$ in a humidified atmosphere containing $5 \% \mathrm{CO}_{2}$ and $95 \%$ oxygen at all times. HCC38 and Vero cells were seeded in 96-well microtiter plates at density $5 \times 10^{4}$ cells/well, whereas MDA361 
cells were plated at $1.25 \times 10^{4}$ cells/well and incubated overnight with respective medium described above to obtain a $70 \%$ confluent layer. The monolayer was treated with different concentrations $(3.125-25 \mu \mathrm{g} / \mathrm{ml})$ of the plant extract/fractions and incubated for $48 \mathrm{~h}$ at $37{ }^{\circ} \mathrm{C}$. In all experiments a negative control and a positive control were maintained. Negative control contained only growth media while the positive control contained $50 \%$ DMSO.

\section{MTT assay}

The principle of MTT is based on cellular reduction of soluble yellow MTT tetrazolium salt (3, 4, 5-(dimethylthiazol-2-yl)-2, 5-diphenyl-tetrazolium bromide) to its purple color formazan product by the mitochondrial dehydrogenase in viable cells. MTT assay was used to determine cytotoxicity of A. hydaspica crude extract/ fractions. After the end of treatment as described above the culture medium was replaced with fresh medium and MTT assay was performed [33]. Absorbance was recorded using a plate reader (Spe $5 \mathrm{M}$ ) on $570 \mathrm{~nm}$, with reference wavelength at $690 \mathrm{~nm}$.

\section{Estimation of cytotoxicity and $I C_{50}$}

Cell cytotoxicity was calculated as a percentage of corresponding control value (non-treated cells) obtained in a minimum of three independent experiments. The halfmaximal inhibitory concentration values $\left(\mathrm{IC}_{50}\right)$, defined as the concentration that inhibits $50 \%$ of cell growth, were calculated from concentration-response curves.

Cytotoxicity was measured using following formula:

$$
\text { Cell survival }(\%)=\left[\frac{\mathrm{At}-\mathrm{Ab}}{\mathrm{Ac}-\mathrm{Ab}}\right] \times 100
$$

Where, At $=$ Absorbance value of test compound, $\mathrm{Ab}=$ Absorbance value of blank, $\mathrm{Ac}=$ Absorbance value of control,

$$
\text { Cell death }(\%)=100-\% \text { Cell survival }
$$

$\mathrm{IC}_{50}$ values were calculated using Graph pad prism 5.

\section{HPLC-DAD analysis}

Preparation of standard for HPLC-DAD Stock solutions of rutin, kaempherol, myricetin, gallic acid, catechin, caffeic acid and quercetin were prepared in methanol at concentration of $1 \mathrm{mg} / \mathrm{ml}$ and diluted with methanol to get 10, 20, 50, 100 and $200 \mu \mathrm{g} / \mathrm{ml}$ for the standard calibration curve. Calibration curves for standard analytes at 10, 20, 50, 100 and $200 \mu \mathrm{g} / \mathrm{ml}$ concentrations were found to be linear.
Preparation of samples for HPLC-DAD Various analytes and plant extract/fractions stock solutions were prepared in methanol, at a concentration of $10-100 \mu \mathrm{g} / \mathrm{ml}$. Samples were filtered through $0.45 \mu \mathrm{m}$ membrane filter (Sortolon polymide; Sortorious). All samples were prepared freshly and used immediately for analysis or stored at $4{ }^{\circ} \mathrm{C}$ if not analyzed for more than $1 \mathrm{~h}$.

Chromatographic condition Chromatographic analysis was carried out by using HPLC-DAD (Agilent Germany) attached with Sorbex RX-C8 (Agilent USA) analytical column. Briefly, mobile phase A was acetonitrile-methanolwater acetic acid (5: 10: 85: 1) and mobile phase B was acetonitrile methanol- acetic acid (40:60:1). A gradient of time $0-20 \mathrm{~min}$ for 0 to $50 \% \mathrm{~B}, 20-25 \mathrm{~min}$ for 50 to $100 \%$ $\mathrm{B}$, and then isocratic $100 \% \mathrm{~B}$ till $40 \mathrm{~min}$ was used. The flow rate was $1 \mathrm{ml} / \mathrm{min}$ and injection volume was $20 \mu \mathrm{l}$. Rutin and gallic acid were analyzed at $257 \mathrm{~nm}$, catechin at $279 \mathrm{~nm}$, caffeic acid at $325 \mathrm{~nm}$ and quercetin, myricetin, kaempferol were analyzed at $368 \mathrm{~nm}$. Every time column was reconditioned for $10 \mathrm{~min}$ before the next analysis. All the samples were assayed in triplicate at ambient temperature. Quantification was carried out by the integration of peak using the external standard method using following formula:

$$
\begin{aligned}
\text { Conc. of SC in sample }= & {\left[\frac{\text { Peak area }(\mathrm{mAU} * \mathrm{~s}) \text { of SC in sample }}{\text { Peak area }(\mathrm{mAU} * \mathrm{~s}) \text { of SC }}\right] } \\
& \times \text { Conc. Of SC }
\end{aligned}
$$

$\mathrm{SC}$ is for standard compound

The concentration of standard compound in each fraction was expressed as $\mu \mathrm{g} / 100$ of dry plant powder.

\section{Statistical analysis}

All assays were performed in triplicates and results are expressed as mean \pm SEM. Data of in vitro antioxidant and anticancer assays was analyzed with help of computerized Graph pad prism software to determine the $\mathrm{EC}_{50}$ and $\mathrm{IC}_{50}$ values. For analyzing the differences among $\mathrm{EC}_{50}$ values of different fractions in different antioxidant assays, a Completely Randomized AOV followed by Tukey HSD All-Pairwise Comparison Test was used, alpha set at 0.05 as a level of significance using Statistix 8.1 software. Correlation analysis was performed to determine the correlation between $\mathrm{EC}_{50}$ of various antioxidant assays and total phenolic and total flavonoid content.

\section{Results and discussion \\ Extraction yield}

Acacia hydaspica crude methanol extract (AHM) yield was $15 \%$ of the dry powder, while AHH, AHE, AHC, AHB and AHA yielded 5.27, 27.77, 1.94, 41.66 and 
$8.05 \%$ respectively, of dry methanol extract. Depending on the nature of solvent used, extraction and fractions yield was recorded differently. AHB and AHE appear to be the best solvents for fractionation giving the maximum yield (Table 1).

\section{Qualitative phytochemical screening}

Diverse assortment of plant secondary metabolites are known to be biologically active compounds and they are responsible for tremendous pharmacological activities for instance antimicrobial, antioxidant, antifungal and anticancer which may benefit in protection against chronic diseases [34]. Table 2 illustrates the qualitative analysis of different classes of phytochemical in $A$. hydaspica methanol extract and its subsequent fractions. Multiple polar and nonpolar chemical constituents were revealed in different extract/fractions of $A$. hydaspica. Tannins, steroids, flavonoid, saponins, cardiac glycosides and terpenoids were found to be present in the all the extract/fractions of $A$. hydaspica plant extract. Alkaloids were detected in all tested extracts except AHC. Coumarins were detected in AHM, AHE and AHA while absent in $\mathrm{AHH}, \mathrm{AHC}$ and $\mathrm{AHB}$. Phlobatannins did not make their presence in AHC and AHA. Presence of reducing sugars and anthraquinones was confirmed only in AHA and in AHM respectively. Tannins, glycosides, saponins and flavonoids have antioxidant, cytotoxic, antitumour hypoglycemic and anti-inflammatory activities [35-37]. Terpenoids, and steroids shows analgesic properties and central nervous system (CNS) activities [38]. Various studies confirm that flavonoid groups exhibit high potential biological activities such as antioxidant, antiinflammatory and anti-allergic reactions [39].

\section{Total phenolic and flavonoid content}

The profile of TPC and TFC in AHM and its derived fractions was determined from the standard calibration curve of gallic acid $\left(R^{2}=0.92\right)$ and rutin $\left(R^{2}=0.91\right)$

Table 1 Extraction yield, total phenolic and flavonoid content in A. hydaspica methanol extract and its soluble fractions

\begin{tabular}{lccr}
\hline Extract/fraction & $\begin{array}{l}\text { Extraction } \\
\text { yield (\%) }\end{array}$ & $\begin{array}{l}\text { TPC (mg gallic acid } \\
\text { equivalent/g dry } \\
\text { sample) }\end{array}$ & $\begin{array}{l}\text { TFC (mg rutin } \\
\text { equivalent/g } \\
\text { dry sample) }\end{array}$ \\
\hline AHM & $15.73^{\mathrm{e}}$ & $87.6 \pm 1.23^{\mathrm{c}}$ & $127 \pm 0.52^{\mathrm{c}}$ \\
$\mathrm{AHH}$ & $5.46^{\mathrm{d}}$ & $57.7 \pm 1.17^{\mathrm{e}}$ & $71 \pm 0.86^{\mathrm{a}}$ \\
$\mathrm{AHE}$ & $27.77^{\mathrm{b}}$ & $120.3 \pm 1.15^{\mathrm{b}}$ & $129 \pm 1.32^{\mathrm{b}}$ \\
$\mathrm{AHC}$ & $1.94^{\mathrm{f}}$ & $36.0 \pm 0.95^{\mathrm{f}}$ & $34.5 \pm 1.13^{\mathrm{d}}$ \\
$\mathrm{AHB}$ & $41.66^{\mathrm{a}}$ & $129 \pm 2.98^{\mathrm{a}}$ & $139 \pm 1.04^{\mathrm{a}}$ \\
AHA & $8.05^{\mathrm{c}}$ & $73.3 \pm 1.53^{\mathrm{d}}$ & $95 \pm 0.05^{\mathrm{c}}$ \\
\hline
\end{tabular}

Value are expressed as mean \pm SEM $(n=3)$; means with superscript with different letters in the columns are significantly $(p<0.05)$ different from each other
Table 2 Phytochemical constituents of A. hydaspica methanol extract and its fractions

\begin{tabular}{lllllll}
\hline Compound Class & \multicolumn{7}{l}{ Samples } & & & \\
\cline { 2 - 6 } & AHM & AHH & AHC & AHE & AHB & AHA \\
\hline Tannins & + & + & + & + & + & + \\
Steroids & + & + & + & + & + & + \\
Saponins & + & + & + & + & + & + \\
Alkaloids & + & + & - & + & + & + \\
Flavonoids & + & + & + & + & + & + \\
Coumarins & + & - & - & + & - & + \\
Terpenoids & + & + & + & + & + & + \\
Pholobatanins & + & + & - & + & + & - \\
Reducing sugars & - & - & - & - & - & + \\
Anthraquinones & + & - & - & - & - & - \\
Cardiac Glycosides & + & + & + & + & + & + \\
\hline
\end{tabular}

Negative sign (-) indicate absence, positive sign (+) indicate presence. AHM Acacia hydaspica methanol extract, AHH Acacia hydaspica n-hexane fraction, AHC Acacia hydaspica chloroform fractions, AHE Acacia hydaspica ethyl acetate fraction, AHB Acacia hydaspica n-butanol fraction, AHA Acacia hydaspica soluble aqueous fraction

respectively. TPC varied widely, ranging from $36.0 \pm 0.95$ to $139 \pm 1.04 \mathrm{mg}$ gallic acid equivalent/g dry sample in the extract/fractions of $A$. hydaspica. However TFC varied from $34.5 \pm 1.13$ to $129.0 \pm 2.98 \mathrm{mg}$ rutin equivalent/ $\mathrm{g}$ of dry sample. AHB showed the highest concentration $(P<0.05)$ of TPC and TFC, followed by AHE $>$ AHM > $\mathrm{AHA}>\mathrm{AHH}>\mathrm{AHC}$ (Table 2). So it is evident from the present data that $\mathrm{AHB}$ and $\mathrm{AHE}$ are the best solvents for fractioning polyphenol constituents, due to their polarity index and the best solubility for the type of metabolites in A. hydaspica. The results obtained in this study were in line to those of Sultana et al. [40], where the highest concentration of TPC had been determined in the bark of Acacia nilotica.

\section{Antioxidant activity assessment}

Various reaction mechanisms are usually involved in measuring the antioxidant capacity of a complex samples and there is no single broad-spectrum system which can give an inclusive, precise and quantitative prediction of antioxidant efficacy and antiradical efficiency [41]. Hence more than one technique is suggested to value the antioxidant potential [42]. The $\mathrm{EC}_{50}$ values of various antioxidants assays were given in Table 3.

\section{DPPH radical scavenging activity}

DPPH free radical quenching test is one among the most widely employed procedures to assess antioxidant potency of plant and biological samples [26]. In the current testing; AHM, AHB and AHE depict appealingly greater DPPH quenching efficacy as compared to all other tested fractions and displayed lower $\mathrm{EC}_{50}$ values, which 
Table 3 EC50 values of different antioxidant activities of extract and derived fractions of A. hydaspica

\begin{tabular}{|c|c|c|c|c|c|c|c|c|c|}
\hline \multicolumn{10}{|c|}{ EC50 values } \\
\hline Sample & DPPH radical & Superoxide radical & Hydroxyl radical & $\begin{array}{l}\text { Hydrogen peroxide } \\
\text { radical }\end{array}$ & ABTS radical & Iron chelating power & $\begin{array}{l}\beta \text {-carotene bleaching } \\
\text { inhibition }\end{array}$ & $\begin{array}{l}\text { Total antioxidant index } \\
\text { at } 250 \mu \mathrm{g} / \mathrm{ml}\end{array}$ & $\begin{array}{l}\text { Lipid peroxidation } \\
\text { inhibition }\end{array}$ \\
\hline $\mathrm{AHM}$ & $19.5 \pm 0.43^{\mathrm{a}}$ & $43.0 \pm 0.37^{b}$ & $39.0 \pm 0.44^{a}$ & $40.3 \pm 0.26^{a}$ & $193 \pm 0.26^{d}$ & $41.7 \pm 0.34^{a}$ & $86.4 \pm 0.62^{d}$ & $1.6 \pm 0.69^{b}$ & $156.1 \pm 0.76^{d}$ \\
\hline $\mathrm{AHH}$ & $46.5 \pm 0.55^{b}$ & $59.3 \pm 0.36^{c}$ & $42.3 \pm 0.29^{b}$ & $80.6 \pm 0.43^{c}$ & $401 \pm 0.23^{e}$ & $91.7 \pm 0.17^{b}$ & $173.5 \pm 0.85^{d}$ & $1.2 \pm 0.35^{c}$ & $562.3 \pm 0.55^{9}$ \\
\hline AHE & $18.0 \pm 0.45^{a}$ & $38.3 \pm 0.40^{a}$ & $35.7 \pm 0.40^{a}$ & $37.2 \pm 0.36^{\mathrm{a}}$ & $173 \pm 0.11^{c}$ & $40.3 \pm 0.21^{a}$ & $48.4 \pm 0.55^{b}$ & $1.7 \pm 0.61^{b}$ & $61.3 \pm 0.52^{c}$ \\
\hline $\mathrm{AHC}$ & $65.0 \pm 0.36^{c}$ & $90.8 \pm 0.55^{d}$ & $63.0 \pm 0.09^{c}$ & $115.6 \pm 1.51^{d}$ & $600 \pm 0.26^{e}$ & $130.1 \pm 0.17^{d}$ & $260.6 \pm 1.05^{f}$ & $0.7 \pm 0.73^{e}$ & $467.3 \pm 0.60^{f}$ \\
\hline$A H B$ & $16.7 \pm 0.43^{\mathrm{a}}$ & $49.0 \pm 0.41^{b}$ & $33.0 \pm 0.16^{\mathrm{a}}$ & $42.0 \pm 0.11^{\mathrm{a}}$ & $98.0 \pm 0.12^{\mathrm{a}}$ & $39.0 \pm 0.26^{\mathrm{a}}$ & $66.2 \pm 0.72^{c}$ & $1.7 \pm 0.41^{a}$ & $50.0 \pm 0.61^{b}$ \\
\hline $\mathrm{AHA}$ & $39.5 \pm 0.51^{b}$ & $46.3 \pm 0.52^{b}$ & $47.0 \pm 0.12^{b}$ & $68.1 \pm 0.36^{b}$ & $478 \pm 0.12^{e}$ & $103.0 \pm 0.12^{c}$ & $131.6 \pm 1.15^{\mathrm{e}}$ & $1.3 \pm 0.14^{e}$ & $401.1 \pm 0.12^{\mathrm{e}}$ \\
\hline AA & $15.0 \pm 0.41^{\mathrm{a}}$ & - & - & $35.0 \pm 0.21^{a}$ & $61.0 \pm 0.21^{b}$ & - & - & $1.8 \pm 0.24^{b}$ & - \\
\hline GA & - & $32.3 \pm 0.28^{\mathrm{a}}$ & $29.0 \pm 0.16^{\mathrm{a}}$ & - & - & - & - & - & $43.5 \pm 0.86^{\mathrm{a}}$ \\
\hline C & - & - & - & - & - & $37.7 \pm 0.3^{\mathrm{a}}$ & $40.4 \pm 1.01^{\mathrm{a}}$ & - & - \\
\hline BHA & - & - & - & - & - & - & & - & $59.3 \pm 0.98^{c}$ \\
\hline BHT & - & - & - & - & - & - & $50.11 \pm 0.59^{b}$ & - & \\
\hline
\end{tabular}

Values are expressed as Mean \pm SEM $(n=3)$. Means with superscripts with different letters in the column are significantly $(P<0.05)$ different from each other. - indicate not determined, $A H M A$. hydaspica methanol extract, $A H H n$-hexane fraction, $A H E$ ethyl acetate fraction, $A H C$ chloroform fraction, $A H B n$-butanol fraction, $A H A$ aqueous fraction, $A A$ Ascorbic acid, GA Gallic acid, $C$ Catechin, $B H A$ butylated hydroxy anisole, $B H T$ butylated hydroxy toluene. (Completely Randomized AOV followed by Tukey HSD All-Pairwise Compariso Test) 
were non-significantly different from one another. The $\mathrm{EC}_{50}$ values in $\mathrm{DPPH}$ assay range from $16.7 \pm 0.43-65 \pm$ $0.36 \mu \mathrm{g} / \mathrm{ml}$. AHB and AHE showed the lowest $\mathrm{EC}_{50}$ values $(16.7 \pm 0.43$ and $18 \pm 0.45 \mu \mathrm{g} / \mathrm{ml})$, which were comparable to $\mathrm{EC}_{50}$ of reference compound (Ascorbic acid). DPPH radical scavenging activity of $A$. hydaspica extract and its various fractions showed good correlation with TPC (R2=0.9879) and TFC $(\mathrm{R} 2=0.8477)$. Results of present investigation imply that $A$. hydaspica contain phyto-constituents that are proficient of donating hydrogen to a free radical in order to rescue the potential impairment. Most specifically, phenolic and flavonoid exhibit antioxidant activity due to the hydroxyl group attach to the aromatic ring which is capable donating electron and stabilizing the free radicals. The research conducted by Sultana et al. [40] in A. nilotica and Singh et al. [43] on Acacia auriculiformis revealed similar results.

\section{Superoxide radical scavenging activity}

Although superoxide anion is a weak oxidant, but it lead to the generation of powerful and hazardous hydroxyl radicals as well as singlet oxygen, both of which contribute to oxidative stress. Therefore, it is very important to study the scavenging of superoxide anion [44]. The $\mathrm{EC}_{50}$ values in superoxide scavenging activities were in the order of $\mathrm{AHE}<\mathrm{AHM}<\mathrm{AHB}<$ $\mathrm{AHA}<\mathrm{AHH}<\mathrm{AHC}$. When compared to ascorbic acid, the superoxide scavenging activity of the AHE was found to be statistically $(P>0.05)$ similar. The potent electron scavenging ability of the methanol extract and its various fractions might be due its bioactive phytoconstituents like that are able to minimize the oxidation of biological macromolecules $[26,37]$. A significant correlation was detected with TPC $\left(\mathrm{R}^{2}=0.7909, P<0.05\right)$ while nonsignificant correlation $\left(R^{2}=0.641, P>0.05\right)$ was observed with TFC. This strong superoxide radical neutralizing capacity of A. hydaspica might be functional therapeutically against oxidative stress induced ailments.

\section{Hydroxyl radical scavenging activity}

The evidence of $\mathrm{OH}$ radical scavenging activity by $A$. hydaspica extract and its fractions was determined by measuring the inhibition of 2-deoxyribose degradation by the free radicals generated during Fenton reaction. Crude methanol extract and derived fractions markedly scavenged $\mathrm{OH}$ radicals and prevented the degradation of 2-deoxyribose. A dose dependent mode was observed for hydroxyl radical scavenging activity. The lowest $\mathrm{EC}_{50}$ values were shown by AHB $(36.0 \pm 0.16 \mu \mathrm{g} / \mathrm{ml})$ followed by AHE and AHM $(37.7 \pm 0.40$ and $40.0 \pm 0.44 \mu \mathrm{g} / \mathrm{ml}$ respectively). However $\mathrm{EC}_{50}$ values were significantly different from standard gallic acid. A significant correlation was observed with TPC $(R 2=0.844, P<0.01)$ and TFC
(R2 = 0.776, $P<0.05)$. The strong antioxidant activity of $\mathrm{AHB}$ and AHE might be utilized as a source of natural antioxidant in oxidative stress for minimizing the detrimental effects of hydroxyl radical in the body. A high scavenging activity of AHE for $\mathrm{OH}$ radical was reported in one of previous studies done in our lab.

\section{Hydrogen peroxide radical scavenging activity}

In the body, $\mathrm{H}_{2} \mathrm{O}_{2}$ is rapidly decomposed into oxygen and water and this may produce hydroxyl radicals $(\bullet \mathrm{OH})$ that can initiate lipid peroxidation and cause DNA damage [6]. Therefore, the ability of plant extracts to scavenge hydrogen peroxide was also determined in order to get the idea that whether samples have same pattern of activity as $\mathrm{OH}$ radical reducing ability. Methanol extract/fractions of $A$. hydaspica possess significant ability to quench the hydrogen peroxide radicals, demonstrating the antioxidant potential of the plant. AHE proved to be efficient fraction against hydrogen peroxide $\quad\left(\mathrm{EC}_{50}=37.2 \pm 0.36 \mu \mathrm{g} / \mathrm{ml}\right) . \quad \mathrm{EC}_{50} \quad$ values showed significant correlation with both TPC $(R 2=$ $0.844, P<0.01)$ and TFC $(\mathrm{R} 2=0.776, P<0.05)$, attributing the activity to the occurrence of polyphenolic compounds that give electrons to hydrogen peroxide, thus neutralizing it into water. These findings are in line with the previous study.

\section{ABTS radical scavenging assay}

In this assay, the reaction of ABTS with potassium persulfate in the existence of hydrogen-donating antioxidants outcomes in the formation of $\mathrm{ABTS}^{+}$blue/green chromophores, this reduction reaction is noted spectrophotometrically at an absorbance of $745 \mathrm{~nm}$. This scheme of determination of antioxidant action is equally pertinent to hydrophilic and lipophilic classes of antioxidants like; flavonoids, hydroxycinnamates, carotenoids and antioxidants in the plasma [45]. The result obtained indicated that AHM and its derived fractions scavenge the ABTS radicals in a dose dependent pattern. Among the extract/fractions lowest $\mathrm{EC}_{50}$ values for ABTS radical scavenging were determined for AHB $(98.0 \pm 0.1 \mu \mathrm{g} / \mathrm{ml})$ while highest $\mathrm{EC}_{50}$ values were recorded for $\mathrm{AHC}(>500$ $\pm 0.26 \mu \mathrm{g} / \mathrm{ml}$ ) as shown in Table 1 . However $\mathrm{EC}_{50}$ values of AHB were significantly lower than ascorbic acid (61 \pm $0.2 \mu \mathrm{g} / \mathrm{ml})$. The ABTS scavenging activity of the present study suggests that the phyto-constituents within the extract and various fractions of $A$. hydaspica might donate electron/hydrogen while minimizing the oxidative stress. Furthermore correlation analysis indicated significant correlation between ABTS radical scavenging activity and TPC $\left(\mathrm{R}^{2}=0.881, P<0.001\right)$ as well as TFC $\left(\mathrm{R}^{2}=\right.$ $0.857, P<0.001)$. The results are in line with the study of khan et al. [46]. 


\section{Chelating activity on Fe2+}

An imperative mechanism of antioxidant activity is the ability to chelate/counteract transition metals, which have the ability to demolish hydro peroxides and Fenton-type reactions. Therefore it was considered important to screen the iron (II) chelating ability of extract/fractions. The sequence for chelating power was $\mathrm{AHB} \sim \mathrm{AHE} \geq \mathrm{AHM}>\mathrm{AHH}>\mathrm{AHA}>\mathrm{AHC}$. The $\mathrm{EC}_{50}$ values of $\mathrm{AHB}, \mathrm{AHE}$ and $\mathrm{AHM}$ were close to the $\mathrm{EC}_{50}$ value of standard catechin. Correlation analysis suggested that the iron (II) chelating possessions of $A$. hydaspica may be accredited to its endogenous chelating agents like polyphenolic compounds [47]. As some phenolic compounds have properly oriented functional groups, which can chelate metal ions to protect against oxidative damage [48]. Chelating activity was correlated well with the phenolic $(\mathrm{R} 2=0.8971, P<0.001)$ and flavonoid content $(\mathrm{R} 2=0.8177, p<0.05)$ Our results are in good agreement with previous report where ethyl acetate fraction possessing polyphenolic constituents of A. auriculiformis showed highest metal chelating power [43].

\section{$\beta$-carotene bleaching inhibition}

In this test, antioxidant competence was evaluated by quantifying the inhibition of the conjugated dienehydroperoxides and the volatile organic compounds creation as an outcome of linoleic acid oxidation. Hence, the antioxidant occurrence can impede the magnitude of $\beta$-carotene bleaching by counterbalancing the linoleate and other free radicals formed in the process. The color of reaction solution was retained for a long time in the presence of an antioxidant compound while a rapid decrease in absorbance was noticed in the absence of antioxidant [49]. The antioxidant activity of A. hydaspica extract/fractions with regard to the $\beta$-carotene bleaching method could be ranked as $\mathrm{AHE}>\mathrm{AHB}>\mathrm{AHM}>$ AHA $>$ AHH $>$ AHC. The $\mathrm{EC}_{50}$ values of AHE $(48.4 \pm$ $0.55 \mu \mathrm{g} / \mathrm{ml}$ ) were significantly different yet comparable with standard catechin $\left(\mathrm{EC}_{50}=40.4 \pm 1.01 \mu \mathrm{g} / \mathrm{ml}\right)$. However AHE showed better efficacy as compared to standard BHT. The differential efficacy of A. hydaspica extract/fractions to inhibit oxidation of linoleic acid emulsion is an indication of the complexity of the extract/fractions as well as potential interaction between the extract and emulsion components. Correlation analysis indicate significant correlation with phenolic $(R 2=$ 0.9670, $P<0.0001)$ and flavonoid $(R 2=0.8831, P<0.001)$ content. The correlation of phenolic and flavonoids with $\beta$-carotene bleaching inhibition potential was reported by other researchers as well $[26,50]$.

\section{Anti-lipid peroxidation potential}

Lipid peroxidation is involved in a number of pathological conditions so evaluation of antioxidant potential of natural and synthetic compounds requires an assay in lipid system too. The $\mathrm{EC}_{50}$ values in lipid peroxidation inhibition were in the order of $\mathrm{AHB}<\mathrm{AHE}<\mathrm{AHM}<\mathrm{AHA}<\mathrm{AHC}<$ $\mathrm{AHH} . \mathrm{EC}_{50}$ values showed by AHB $(50 \pm 0.61 \mu \mathrm{g} / \mathrm{ml})$ were significantly lower as compared to $\mathrm{BHA}$ values $\left(\mathrm{EC}_{50}=\right.$ $59.3 \pm 0.98 \mu \mathrm{g} / \mathrm{ml})$. In this study the in vitro ability of plant extract/fractions to prevent the production of TBARS depicts the potential of samples to inhibit oxidation in lipid system. Significant correlation was observed with TPC $\left(R^{2}=0.779, P<0.05\right)$ and TFC $\left(R^{2}=0.836, P\right.$ $<0.05)$. Phenolic compounds are very important plant constituents because they exhibit antioxidant activities by inactivating lipid free radicals, or by preventing the decomposition of hydro-peroxides into free radicals. Results of lipid peroxidation were in line with the previous study of Singh et al. [43].

\section{Total antioxidant capacity assay}

The total antioxidant capacity of the extract/fractions was measured by phosphomolybdenum method based on the reduction of molybnedum (VI) to molybnedum (V) by the antioxidant action of extract and the subsequent formation of a green phosphate Mo (V) complex at acid $\mathrm{pH}$ of the medium with maximum absorbance at $695 \mathrm{~nm}$ [51]. Total antioxidant capacity of the extract/ fractions recorded at the highest dose of $250 \mu \mathrm{g} / \mathrm{ml}$ was in order of AHB $(1.7 \pm 0.015) \sim \mathrm{AHE}(1.7 \pm 0.08)>\mathrm{AHM}$ $(1.5 \pm 0.016)>$ AHA $\quad(1.3 \pm 0.05)>$ AHH $\quad(1.2 \pm 0.02)>$ AHC $(0.738 \pm 0.012)$. The current analysis reveals that AHB and AHE displayed the uppermost antioxidant capacity. Latest researches proved that flavonoids and related polyphenols contributes substantially to the phosphomolybdate quenching capability of medicinal plants [46, 52]. AHB and AHE exhibited the highest antioxidant index comparable with ascorbic acid. Phosphomolybdenum assay in general detects antioxidants such as carotenoids, ascorbic acid, $\alpha$-tocopherol, and some phenolic, cysteine, and aromatic amines due to hydrogen and electron donating ability. The antioxidant capacities of the extract/fractions have a strong relationship with the solvent employed, mainly due to the different antioxidant potential of compounds with different polarities. Phytochemical analysis reveals the presence of various boiactive phytochemicals that might be attributed to the antioxidant capacity of A. hydaspica. Our result correlate well with the research of Tung at al. reporting gallic acid, catechin, myricetin along with other polyphenols in $A$. confusa leaves extract were responsible for the significant antioxidant potential [53].

\section{Reducing power}

Samples owning more reducing efficacy displayed high absorbance values. From the literature, it's evident that reducing power is attributed to the existence of 


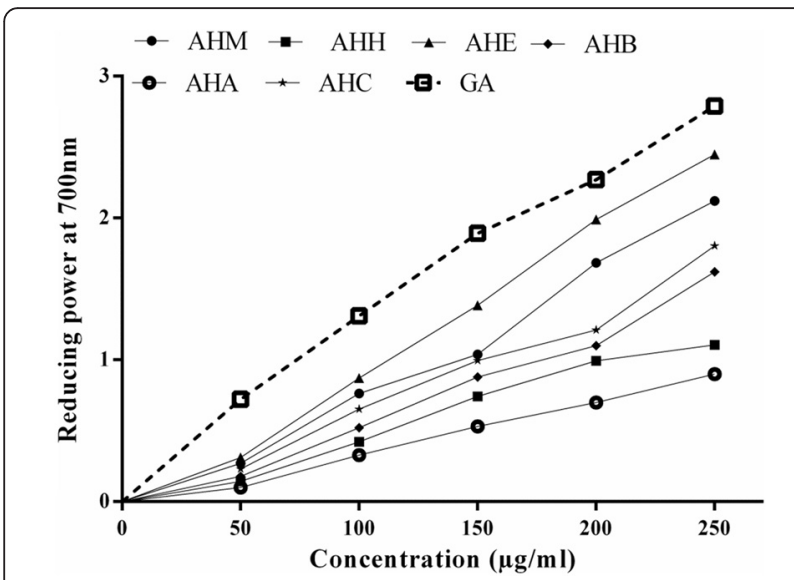

Fig. 1 Dose dependent reducing power activity of extract and fractions of $A$. hydaspica. Values are expressed as mean $\pm \operatorname{SEM}(n=3)$. $G A$ Gallic acid used as reference

antioxidants that contributes hydrogens atoms to the free radicals [54]. It was observed that reducing power of the extract/fractions was increased in a dose dependent manner. The reducing power of the extract and various fractions was in an order of AHE $>\mathrm{AHB}>\mathrm{AHM}>\mathrm{AHH}>$ AHC $>$ AHA. The AHE and AHM exhibited an excellent reducing power of $2.5 \pm 0.024$ and $2.3 \pm 0.09$ at a concentration of $250 \mu \mathrm{g} / \mathrm{ml}$ (Fig. 1). AHE at $250 \mu \mathrm{g} / \mathrm{ml}$ showed good reducing power that was comparable to standard Gallic acid. The significant reducing potential of AHE might be credited to the elevated amount of polyphenols that may function as indicator of its potential antioxidant action. These results are in agreement with the previous study where ethyl acetate extract of $A$. auriculiformis bark exhibit significant reducing potential [43].

\section{Anti-hemolytic activity}

The most plentiful cells in the human body are found to be the erythrocytes, which own copious biological and morphological characteristics, hence they have been widely exploited in drug transport. The polyunsaturated fatty acids (PUFA) and hemoglobin molecules which are redox active oxygen transport molecules and potent promoters of activated oxygen species mainly target the erythrocytes. Oxidative mutilation to the erythrocyte membrane lipids and proteins may be responsible for hemolysis accompanying with several factors viz. hemoglobinopathies, oxidative drugs, excess of transition metals, various radiation, and deficiencies in erythrocyte antioxidant coordination $[55,56]$. The magnitude of hemolysis was appeared to be much more overwhelming, when red blood cells were exposed to any toxicant like hydrogen peroxide [57]. This experiment was aimed to assess whether $A$. hydaspica prevented oxidative damages to erythrocyte membrane or not. Acacia hydaspica methanol extract and its various fractions showed differential pattern of anti-hemolytic activity. Results indicated that AHM, AHE and AHB exhibited potent anti-hemolytic action in a dose dependent way. However maximum inhibition of hemolysis was exhibited by AHE (97 \% RBC membrane stabilization) at $1000 \mu \mathrm{g} / \mathrm{ml}$, whereas aqueous fraction exhibit minimum anti-hemolytic activity as compared to other fractions (Table 4). Lysis of erythrocytes was displayed to be decreased with an increase in concentration of extract or fraction.

The outcome of the current experiment presents the occurrence of primary antioxidants, which possess antihemolytic effect.

\section{Assessment of anticancer potential by MTT assay}

Maximum numbers of the anticancer drugs presently consumed in chemotherapy are cytotoxic to healthy cells, consequences in excessive anomalies. Based on the antioxidant ability of the extract/fractions of $A$. hydaspica; AHM, AHE and AHB were selected for cytotoxic testing against cancer and normal cell lines. The

Table 4 Anti-hemolytic activity of A. hydaspica methanol extract and its soluble fractions against $\mathrm{H}_{2} \mathrm{O}_{2}$ induced hemolysis

\begin{tabular}{|c|c|c|c|c|c|c|c|}
\hline \multirow[t]{2}{*}{ Samples } & \multirow[t]{2}{*}{ Positive control (A) } & \multirow[t]{2}{*}{ Negative control (B) } & \multicolumn{4}{|c|}{ Optical density ${ }^{C}$ at $560 \mathrm{~nm}$ concentration $(\mu \mathrm{g} / \mathrm{ml})$} & \multirow{2}{*}{$\begin{array}{l}\% \text { Inhibition of hemolysis } \\
\text { at } 1000(\mu \mathrm{g} / \mathrm{ml})\end{array}$} \\
\hline & & & 100 & 250 & 500 & 1000 & \\
\hline$\overline{\mathrm{AHM}}$ & $1.45 \pm 0.02$ & $0.11 \pm 0.05$ & $0.69 \pm 0.01$ & $0.85 \pm 0.05$ & $0.96 \pm 0.05$ & $1.15 \pm 0.01$ & $79.3^{c}$ \\
\hline $\mathrm{AHH}$ & $1.45 \pm 0.03$ & $0.11 \pm 0.05$ & $0.65 \pm 0.05$ & $0.71 \pm 0.05$ & $0.88 \pm 0.05$ & $0.98 \pm 0.05$ & $67.6^{d}$ \\
\hline $\mathrm{AHC}$ & $1.45 \pm 0.05$ & $0.11 \pm 0.05$ & $0.51 \pm 0.05$ & $0.63 \pm 0.03$ & $0.71 \pm 0.05$ & $0.87 \pm 0.02$ & $60.0^{\mathrm{e}}$ \\
\hline AHE & $1.45 \pm 0.06$ & $0.11 \pm 0.05$ & $0.72 \pm 0.04$ & $0.89 \pm 0.09$ & $1.14 \pm 0.01$ & $1.42 \pm 0.02$ & $97.9^{\mathrm{a}}$ \\
\hline AHB & $1.45 \pm 0.04$ & $0.11 \pm 0.05$ & $0.67 \pm 0.05$ & $0.81 \pm 0.05$ & $0.92 \pm 0.05$ & $1.29 \pm 0.03$ & $88.9^{b}$ \\
\hline $\mathrm{AHA}$ & $1.45 \pm 0.07$ & $0.11 \pm 0.05$ & $0.49 \pm 0.05$ & $0.59 \pm 0.05$ & $0.64 \pm 0.05$ & $0.79 \pm 0.05$ & $54.5^{f}$ \\
\hline QR & $1.45 \pm 0.08$ & $0.11 \pm 0.05$ & $0.72 \pm 0.04$ & $0.89 \pm 0.09$ & $1.14 \pm 0.01$ & $1.43 \pm 0.02$ & $98.6^{\mathrm{a}}$ \\
\hline
\end{tabular}

Each value is represented as mean \pm SEM $(n=3)$. Values in same column followed by different letter $\left({ }^{\text {a-f }}\right)$ are significantly different $(p<0.05)$, A; phosphate buffer saline replaced extract/fraction as this treatment results in $0 \%$ hemolysis, $\mathrm{B}$; hydrogen peroxide replaced extract to serve as a negative control since this treatment results in $100 \%$ hemolysis, c; lower values are associated with increased cell lysis. AHM A. hydaspica methanol extract, AHH A. hydaspica nhexane fraction, AHE A. hydaspica ethyl-acetate. (Completely Randomized AOV followed by Tukey HSD All-Pairwise Comparison Test) 
Table 5 Cytotoxic effect of A. hydaspica methanol extract and its derived fractions on MDA-MB 361, HCC-38 and Vero cells of green monkey after $48 \mathrm{~h}$ of treatment

\begin{tabular}{|c|c|c|c|c|c|}
\hline \multirow[t]{2}{*}{ Extract/Fraction } & MDA361 cell line & $\mathrm{SI}$ & HCC38 cell line & $\mathrm{SI}$ & Vero cell line \\
\hline & $\mid C_{50}(\mu \mathrm{g} / \mathrm{ml})$ & $I C_{50} \mathrm{~V} / \mathrm{IC}_{50} \mathrm{M}$ & $\mid C_{50}(\mu \mathrm{g} / \mathrm{ml})$ & $\mathrm{IC}_{50} \mathrm{~V} / \mathrm{I} \mathrm{C}_{50} \mathrm{H}$ & $\mathrm{IC}_{50}(\mu \mathrm{g} / \mathrm{ml})$ \\
\hline $\mathrm{AHM}$ & $46.9 \pm 1.31^{*}$ & 5.42 & $75.9 \pm 1.32^{*}$ & 3.34 & $254 \pm 1.81$ \\
\hline AHE & $29.9 \pm 0.91^{*}$ & 9.83 & $39.5 \pm 0.87^{*}$ & 7.44 & $294 \pm 1.55$ \\
\hline AHB & $37.1 \pm 1.01^{*}$ & 6.97 & $56.1 \pm 0.93^{*}$ & 4.60 & $258 \pm 1.68$ \\
\hline
\end{tabular}

Each value expressed as mean $\pm \mathrm{SEM}(n=3)$. Selectivity index $(\mathrm{SI})>3$ is considered to be highly selective, ${ }^{*}$ shows significance at $p<0.001$ as compared to Vero cells. M represents MDA-MB-361; V represents Vero and H represents HCC38 cell lines. (One way ANOVA followed by Tukey's multiple comparison test)

integration of cancer and normal cells in the study design are necessary for the detection of cyto-selective compounds. The result of MTT assay revealed that tested samples inhibited cell proliferation in a dose dependent manner, although their effects were different from one another. $\mathrm{IC}_{50}$ values of extract/fractions at all tested cell lines exhibited a distinctive pattern (Table 5). AHM, AHE and AHB showed no cytotoxicity against normal Vero cells as shown by higher $\mathrm{IC}_{50}$ values $\left(\mathrm{IC}_{50}>250 \mu \mathrm{g} / \mathrm{ml}\right)$. AHE was found the most effective against cancer cells, with $\mathrm{IC}_{50}$ values found to be $29.9 \pm 0.909 \mu \mathrm{g} / \mathrm{ml}$ for MDA-MB-361 cell line and $39.5 \pm 0.872 \mu \mathrm{g} / \mathrm{ml}$ for $\mathrm{HCC}-38$ cell line. $\mathrm{IC}_{50}$ values and selectivity indices (SI) of different samples against cancer cells and normal cells were shown in Table 5 . Most of the anticancer drugs currently used in chemotherapy are cytotoxic to normal cells, leading to unwanted side effects. The current study provides a significant bearing in search for compounds, which can reduce the harmful side effects of anticancer drugs, as A. hydaspica extract/fractions showed significant cyto-selective effect indicated by higher selectivity index values. Phytochemical investigation indicates the presence of bioactive metabolites in active extract/fractions might contribute to inhibiting cell viability in cancer cells. Our results are in agreement with the previous study of Kalaivani et al., demonstrating that distinct effect of A. nilotica extracts in each cell line might be due to the phyto-diversity or varied mechanisms accompanying each of the compounds [58]. Flavonoids have been presented little or no cytotoxic effect on healthy cells while being cytotoxic against various human cancer cells [59]. Flavonoids mediate their actions by various ways i.e., simply binds to the cell membrane, penetrate in vitro cultured cells or via modulation of the cellular metabolic activities. Extenuation of oxidative damage, carcinogen inactivation, inhibition of cell growth and differentiation, induction of cell cycle arrest and apoptosis, diminishing of tumor angiogenesis and restriction of metastasis are the major implications of flavonoids anti-carcinogenic activities $[60,61]$. The cyto-protective effect of extract against normal cell depict that $A$. hydaspica selectively inhibited the growth of cancer cell types and did not induce cell death in normal cells indicating the anticancer activity of A. hydaspica. This calls for further studies on the active components for proper assessment of their chemotherapeutic properties as well as their possible development as promising anticancer drugs.

\section{HPLC-DAD analysis}

HPLC-DAD analysis is the best way for chemical profiling of plant extract, therefor rapid, reproducible and specific finger printing was established in the current research work. AHB and AHE showed excellent antioxidant, antihemolytic and anticancer activities hence subjected for chemical profiling by HPLC-DAD. Gallic acid, catechins, caffeic acid, rutin, kaempferol, myricetin and Our result correlate well with quercetin were used as markers to compare retention time and UV absorbance with test samples. Table 6 indicated the retention time, optimized signal wavelength, and regression analysis of reference flavonoids. HPLC-DAD chromatogram reveals the presence of two known compounds gallic acid (144.70 $\mu \mathrm{g} / 100 \mathrm{mg}$ dry powder) and catechin (3995.208 $\mu \mathrm{g} / 100 \mathrm{mg}$ dry powder) in AHB, whereas AHE showed three reference compounds with maximum amount shown by catechin $(8648 \mu \mathrm{g} / 100 \mathrm{mg}$ dry powder) followed by gallic acid $(52.92 \mu \mathrm{g} / 100 \mathrm{mg}$ dry powder) and myricetin $(34.60 \mu \mathrm{g} / 100 \mathrm{mg}$ dry powder $)$ (Fig. 2a and b, Table 7).

Table 6 Retention time, optimized signal wavelength, and regression analysis of reference flavonoids determined by HPLC-DAD analysis

\begin{tabular}{llcll}
\hline Compound & $\begin{array}{l}\text { Signal } \\
\text { wavelength }\end{array}$ & $\begin{array}{c}\text { Retention } \\
\text { time }(\mathrm{min})\end{array}$ & Regression analysis & $\mathrm{R}^{2}$ \\
\hline Gallic acid & 257 & 4.35 & $\mathrm{y}=3.0565 x+8.01$ & 0.9998 \\
Rutin & 257 & 15.91 & $\mathrm{y}=1.7773 x-48.49$ & 0.9958 \\
Catechin & 279 & 9.70 & $y=1.1764 x+7.96$ & 0.989 \\
Caffeic acid & 325 & 325 & $y=12.569 x+22.66$ & 0.9905 \\
Apigenin & 325 & 23.53 & $y=12.950 x-52.12$ & 0.9957 \\
Myricetin & 368 & 18.72 & $y=2.560 x-15.09$ & 0.9994 \\
Kaempherol & 368 & 23.59 & $y=10.967 x+125.59$ & 0.9964 \\
Quercetin & 368 & 21.31 & $y=4.8624 x+35.01$ & 0.9993 \\
\hline
\end{tabular}




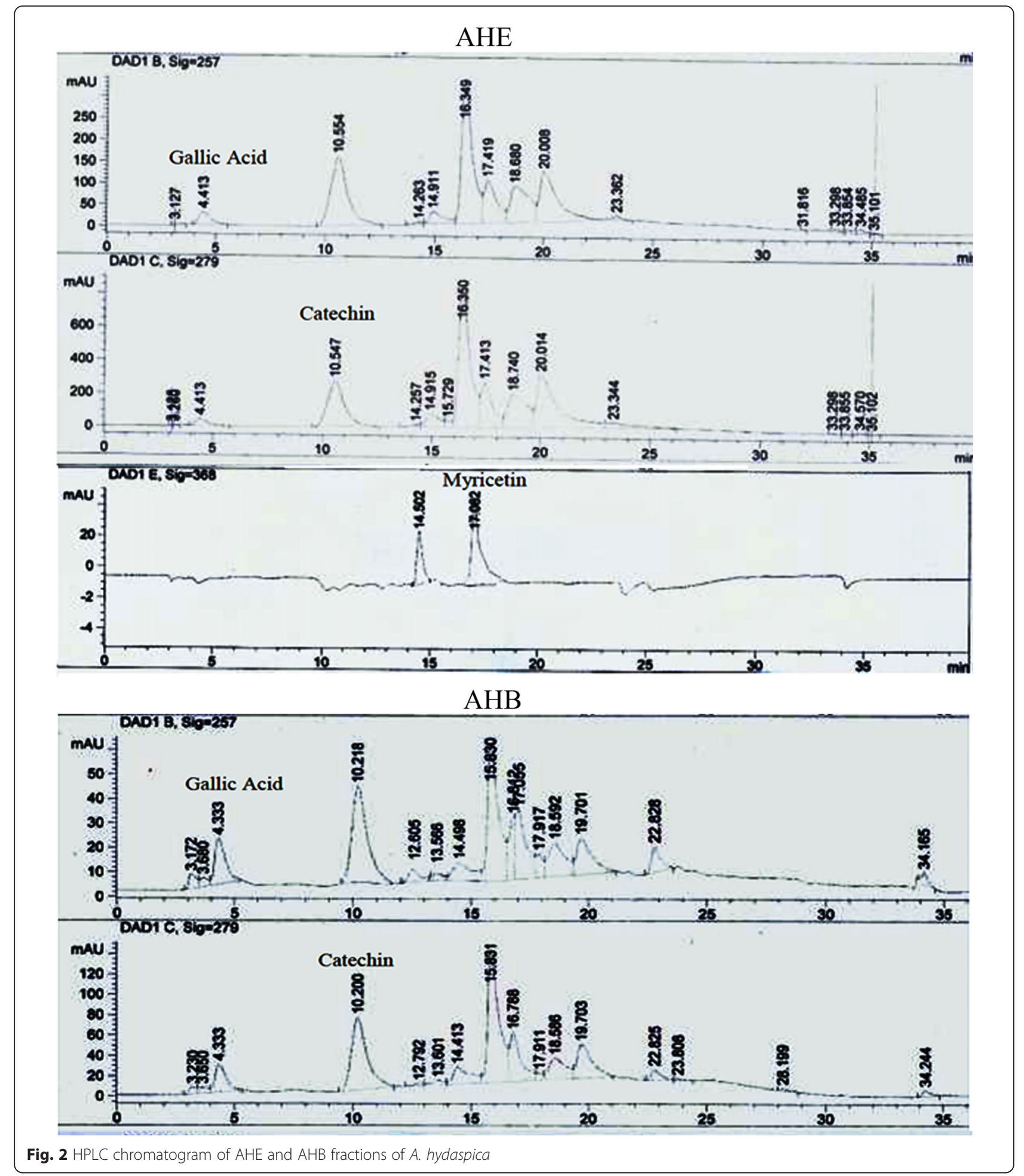

The standards were selected on the basis of their reported medicinal properties, for instance; catechin is an important phenolic compound with diverse beneficial health effects and its metabolites have shown therapeutic potential as antioxidant, antiapoptotic, inhibit proliferation of breast cancer cells, block carcinogenesis and its effect is more pronounced in cancer cells as compared to normal cells [62]. Gallic acid (GA) possesses potent antitumoral and antioxidant properties. The research conducted by Ali et al. also illustrate that gallic acid and polyphenols in the acetone extract of A. nilotica, are 
Table 7 HPLC-DAD profile of A. hydaspica ethyl acetate and n-butanol fractions

\begin{tabular}{lllcc}
\hline Extract/fraction & Compounds & $\begin{array}{l}\text { Signal } \\
\text { wavelength }\end{array}$ & $\begin{array}{l}\text { Retention } \\
\text { time }\end{array}$ & $\begin{array}{l}\text { Quantity } \\
(\mu \mathrm{g} / 100 \mathrm{mg} \\
\text { dry powder })\end{array}$ \\
\hline AHE & Gallic acid & $275 \mathrm{~nm}$ & 4.52 & 52.92 \\
& Catechin & $279 \mathrm{~nm}$ & 11.43 & 8648.0 \\
& Myricetin & $368 \mathrm{~nm}$ & 17.08 & 34.60 \\
AHB & Gallic acid & $257 \mathrm{~nm}$ & 4.41 & 144.70 \\
& Catechin & $279 \mathrm{~nm}$ & 10.55 & 3995.21 \\
\hline
\end{tabular}

responsible for cytotoxic activity [63]. Myricetin is also able to induce apoptosis of pancreatic cancer cells, human bladder carcinoma cell line, trigger apoptosis, regression of tumor growth, decrease metastasis and it increase bioavailability of tamoxifen, a drug used to treat breast cancer [64].

Our result correlate well with the research of Tung at al., reporting gallic acid, catechin, myricetin along with other polyphenols in ethyl acetate fraction of $A$. confusa leaves extract were responsible for the significant antioxidant and anticancer potential [53]. This calls for further studies on the active components for proper assessment of their chemotherapeutic properties as well as their possible development as promising anticancer drugs.

\section{Conclusion}

The present study demonstrates the phytochemical profiling, in vitro antioxidant, anti-hemolytic and cyto-selective anticancer activity of A. hydaspica aerial parts extracts. Extracts with higher antioxidant capacity also had higher polyphenol content. It can be concluded that the extract obtained using higher polarity solvents were more effective radical scavengers then those obtained using less polar solvents. Ethyl acetate and $n$-butanol showed better characteristics as solvent for phenolic compounds. Furthermore these fractions tended to possess superior activity in lipid peroxidation inhibition and $\beta$-carotene bleaching assay as compared to BHA and BHT. Therefore, they might be used as preservative ingredients in the food and/or pharmaceutical industry. Moreover safety profile and chemotherapeutic potential of active fractions and methanol extract was determined by assessing the anti-hemolytic activity and in vitro testing against both cancer and normal cell lines. Bioactive compounds present in $A$. hydaspica active fractions might work synergistically and specifically in inhibiting proliferation of breast cancer cells with high SI value, suggesting that they might be used as a natural additive in human diets for cancer chemoprevention. However the evaluation and the discovery of new anticancer agents is long-term process that encompasses many steps by step approaches with the screening for anticancer properties, followed by the isolation and identification of bioactive compounds and finally in vivo anticancer activity testing in order to verify the aptitude of the compounds. Therefore further research would be required before such uses could be proposed with confidence.

\section{Abbreviations \\ ABTS, 2,2'-azino-bis (3-ethylbenzothiazoline-6-sulphonic acid; AHA, Acacia hydaspica residual aqueous fraction of methanol extract of aerial parts; $A H B$ Acacia hydaspica n-butanol fraction of methanol extract of aerial parts; AHC, Acacia hydaspica chloroform fraction of methanol extract of aerial parts; AHE, Acacia hydaspica ethyl acetate fraction of methanol extract of aerial parts; $\mathrm{AHH}$, Acacia hydaspica n-hexane fraction of methanol extract of aerial parts; AHM, Acacia hydaspica methanol extract of aerial parts; BHA, butylated hydroxyanisole; BHT, butylated hydroxytoluene; DMEM/F12, Dulbecco's modified eagle medium: nutrient mixture F-12; DPPH, 2,2-Diphenyl-1- Picrylhydrazyl; EDTA, ethylene diamine tetra acetic acid; PBS, phosphate buffer saline; PMS, phenazine methosulphate; TBA, thiobarbituric acid; TBARS, thiobarbituric acid reactive substances; TFC, total flavonoid content; TPC, total phenolic content}

\section{Acknowledgements}

We acknowledge Higher Education Commission (HEC) of Pakistan for awarding indigenous scholarship and IRSP scholarship for University of Minnesota, USA to the first author. Furthermore we acknowledge Deanship of Scientific Research at King Saud University for its technical assistant in this research project

\section{Funding}

The project was partially funded by the Higher Education Commission (HEC) of Pakistan by awarding indigenous scholarship to the first author. We are grateful to the Deanship of Scientific Research at King Saud University for its funding of this research through Research Group Project number 193.

\section{Availability of data and materials}

All the data is contained in the manuscript.

\section{Authors' contributions}

TA made significant contributions to conception, design, experimentation, acquisition and interpretation of data and writing of manuscript. SR, MRK, SM, AA and MS made substantial contribution in interpretation of data and revising the manuscript for intellectual content. IUH made a contribution to the HPLC experimentation and analysis. All authors read and approved the final manuscript.

\section{Authors' information}

TA did PhD in Biochemistry/Pharmacological biology from Department of Biochemistry, Quaid-i-Azam University, Islamabad, Pakistan. SR is PhD Scholar from Department of Animal Sciences, Faculty of Biological Sciences, Quaid-iAzam University, Islamabad and Researcher at the Department of Community Health Sciences, College of Applied Medical Sciences, Clinical nutrition program, King Saud University, Riyadh KSA. MRK did his Diploma in Unani Medicine and Surgery (DUMS) and is a registered practitioner of the National Council for Tibb of Pakistan. He is working as Associate Professor at the Department of Biochemistry, Quaid-i-Azam University, Islamabad, Pakistan. SM did MPhil in biochemistry/Pharmacological biology from Department of Biochemistry, Quaid-i-Azam University, Islamabad, Pakistan. AA is associate professor at Department of Community Health Sciences, College of Applied Medical Sciences, Clinical nutrition program, King Saud University, Riyadh KSA. MS did PhD in Biochemistry/Pharmacological biology from Department of Biochemistry, Quaid-i-Azam University, Islamabad, Pakistan. IUH is assistant professor at the Department of Pharmacy, Faculty of Biological Sciences, Quaid-i-Azam University, Islamabad, Pakistan. 


\section{Consent for publication}

Not applicable.

\section{Ethics approval and consent to participate}

This study makes use of rats and human blood, and the experimental protocol for the use of animal and human blood was approved (Bch\#0256) by the ethical board of Quaid-i-Azam University, Islamabad Pakistan.

\section{Author details}

${ }^{1}$ Department of Biochemistry, Faculty of Biological Sciences, Quaid-i-Azam University, Islamabad, Pakistan. ${ }^{2}$ Department of Animal Sciences, Faculty of Biological Sciences, Quaid-i-Azam University, Islamabad, Pakistan.

${ }^{3}$ Department of Community Health Sciences, College of Applied Medical Sciences, King Saud University, Riyadh, Kingdom of Saudi Arabia. ${ }^{4}$ Department of Pharmacy, Faculty of Biological Sciences, Quaid-i-Azam University, Islamabad, Pakistan.

\section{Received: 4 December 2015 Accepted: 23 July 2016}

Published online: 29 July 2016

\section{References}

1. Mena S, Ortega A, Estrela J. Oxidative stress in environmental-induced carcinogenesis. Mutat Res Genet Toxicol Environ Mutagen. 2009;674(1): $36-44$.

2. Waris $\mathrm{G}$, Ahsan $\mathrm{H}$. Reactive oxygen species: role in the development of cancer and various chronic conditions. J Carcinog. 2006;5(1):14.

3. Sasaki Y, Kawaguchi S, Kamaya A, Ohshita M, Kabasawa K, Iwama K, Taniguchi K, Tsuda S. The comet assay with 8 mouse organs: results with 39 currently used food additives. Mutat Res Genet Toxicol Environ Mutagen. 2002;519(1):103-19.

4. Soobrattee M, Bahorun T, Aruoma O. Chemopreventive actions of polyphenolic compounds in cancer. Biofactors. 2006;27(1-4):19-35.

5. Dai J, Mumper R. Plant phenolics: extraction, analysis and their antioxidant and anticancer properties. Molecules. 2010;15(10):7313-52.

6. Rj R, Cheng S-J, Je K. Prevention of cytotoxicity and inhibition of intercellular communication by antioxidant catechins isolated from Chinese Green Tea. Carcinogenesis. 1989;10(6):1003-8.

7. Chakrabarty T, Gangopadhyay M. The genus Acacia P. Miller (Leguminosae: Mimosoideae) in India. J Econ Taxon Bot. 1996;20(3):599-633.

8. Jabeen A, Khan Ma, Ahmad M, Zafar M, Ahmad F. Indigenous uses of economically important Flora of Margallah Hills National Park, Islamabad, Pakistan. African J Biotechnol. 2009;8(5):763-784

9. Afsar T, Khan M, Razak S, Ullah S, Mirza B. Antipyretic, anti-inflammatory and analgesic activity of Acacia Hydaspica R. Parker and its phytochemical analysis. BMC Complement Altern Med. 2015:15:136

10. Afsar T, Trembley J, Salomon C, Razak S, Khan M, Ahmed K. Growth inhibition and apoptosis in cancer cells induced by polyphenolic compounds of Acacia Hydaspica: involvement of multiple signal transduction pathways. Sci Rep. 2016;6:23077.

11. Malviya S, Rawat S, Kharia A, Verma M. International Journal of Pharmacy \& Life Sciences. Int J Pharm Life Sci(ljpls). 2011;2(6):830-7.

12. Chang S-T, Wu J-H, Wang S-Y, Kang P-L, Yang N-S, Shyur L-F. Antioxidant activity of extracts from Acacia Confusa bark and heartwood. J Agric Food Chem. 2001:49(7):3420-4.

13. Mihara R, Barry K, Mohammed C, Mitsunaga T. Comparison of antifungal and antioxidant activities of Acacia Mangium and A. Auriculiformis heartwood extracts. J Chem Ecol. 2005;31(4):789-804.

14. Tung Y-T, Wu J-H, Huang C-Y, Kuo Y-H, Chang S-T. Antioxidant activities and phytochemical characteristics of extracts from Acacia Confusa Bark. Bioresour Technol. 2009;100(1):509-14

15. Ghate N, Hazra B, Sarkar R, Mandal N. Heartwood extract of Acacia Catechu induces apoptosis in human breast carcinoma by altering Bax/Bcl-2 ratio. Pharmacogn Mag. 2014;10(37):27.

16. Siddiqui A, Ali M. Practical pharmaceutical chemistry. Cbs Publishers Distrib New Delhi. 1997;126:131

17. Sofowora A. Recent trends in research into African medicinal plants. J Ethnopharmacol. 1993;38(2):197-208.

18. Trease G. Trease and Evans' pharmacognosy. London: Bailliere Tindal; 1989.

19. Talukdar A, Choudhury M, Chakraborty M, Dutta B. Phytochemical screening and tlc profiling of plant extracts of Cyathea Gigantea (Wall. Ex. Hook.) Haltt. and Cyathea Brunoniana. Wall. Ex. Hook (Cl. \& Bak.). Assam Univ J Sci Technol. 2010:5(1):70-4.

20. Harborne Jb. Phytochemical Methods. Springer. 1984;278:37-99.

21. Mcdonald J, O'dwyer S, Rout S, Chakrabarty B, Sikand K, Fulford P, Wilson M, Renehan A. Classification of and Cytoreductive surgery for low-grade Appendiceal Mucinous Neoplasms. Br J Surg. 2012;99(7): 987-92.

22. Chang C-C, Yang M, Wen $\mathrm{H}$, Chern J. Estimation of total flavonoid content in propolis by two complementary colorimetric methods. J Food Drug Anal. 2002;10(3):178-82

23. Brand-Williams W, Cuvelier M, Berset C. Use of a free radical method to evaluate antioxidant activity. LWT-Food Scie Technol. 1995;28(1):25-30.

24. Nishikimi M, Rao N, Yagi K. The occurrence of superoxide anion in the reaction of reduced phenazine methosulfate and molecular oxygen. Biochem Biophys Res Commun. 1972:46(2):849-54.

25. Gutteridge J, Halliwell B. Free radicals and antioxidants in the year 2000 a historical look to the future. Ann N Y Acad Sci. 2000:899(1):136-47.

26. Sahreen S, Khan M, Khan R. Evaluation of antioxidant activities of various solvent extracts of Carissa Opaca fruits. Food Chem. 2010;122(4):1205-11.

27. Re R, Pellegrini N, Proteggente A, Pannala A, Yang M, Rice-Evans C. Antioxidant activity applying an improved Abts radical cation decolorization assay. Free Radic Biol Med. 1999;26(9):1231-7.

28. Beauchamp C, Fridovich I. Superoxide dismutase: improved assays and an assay applicable to acrylamide gels. Anal Biochem. 1971;44(1):276-87.

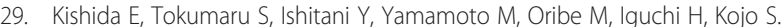
Comparison of the formation of malondialdehyde and thiobarbituric acid-reactive substances from autoxidized fatty acids based on oxygen consumption. J Agric Food Chem. 1993:41(10):1598-600

30. Umamaheswari M, Chatterjee T. In vitro antioxidant activities of the fractions of Coccinia Grandis L. Leaf extract. Afr J Tradit Complement Altern Med. 2008;5(1):61-73

31. Kumaran A. Antioxidant and free radical scavenging activity of an aqueous extract of Coleus Aromaticus. Food Chem. 2006;97(1):109-14.

32. Yang Z-G, Sun H-X, Fang W-H. Haemolytic activities and adjuvant effect of Astragalus Membranaceus Saponins (Ams) on the immune responses to ovalbumin in mice. Vaccine. 2005:23(44):5196-203.

33. Mosmann T. Rapid colorimetric assay for cellular growth and survival: application to proliferation and cytotoxicity assays. J Immunol Methods. 1983;65(1):55-63.

34. Akhtar N, Mirza B. Phytochemical analysis and comprehensive evaluation of antimicrobial and antioxidant properties of 61 medicinal plant species. Arab J Chem. 2015. doi:10.1016/j.arabjc.2015.01.013.

35. Lu X-L, Qiu S-S, Sun X-X, Li Z-J. Preliminary study on the capability of antioxidation and scavenging free radicals of sasanquasaponins [J]. Food Sci. 2005;11:016.

36. Beninger C, Hosfield G. Antioxidant activity of extracts, condensed tannin fractions, and pure flavonoids from Phaseolus Vulgaris L. Seed Coat color genotypes. J Agric Food Chem. 2003;51(27):7879-83.

37. Cai Y, Luo Q, Sun M, Corke H. Antioxidant activity and phenolic compounds of 112 traditional Chinese medicinal plants associated with anticancer. Life Sci. 2004;74(17):2157-84.

38. Sangeetha S, Deepa M, Sugitha N, Mythili S, Sathiavelu A. Antioxidant activity and phytochemical analysis of Datura Metel. Int J Drug Dev Res. 2014;6(4):46-53

39. Korkina L, Ib Afanas' E. Antioxidant and chelating properties of flavonoids. Adv Pharmacol. 1996;38:151-63.

40. Sultana B, Anwar F, Przybylski R. Antioxidant activity of phenolic components present in barks of Azadirachta Indica Terminalia Arjuna Acacia Nilotica and Eugenia Jambolana Lam. Trees Food Chem. 2007;104(3):1106-14.

41. Shah Na, Khan Mr, Naz K, Khan Ma. Antioxidant potential, Dna protection, and Hplc-dad analysis of neglected Medicinal Jurinea Dolomiaea roots. Biomed Res Int. 2014;2014:726241.

42. Oi A. Methodological considerations for characterizing potential antioxidant actions of bioactive components in plant foods. Mutat Res Fundam Mol Mech Mutagen. 2003;523:9-20.

43. Singh R, Singh S, Kumar S, Arora S. Evaluation of antioxidant potential of Ethyl Acetate Extract/Fractions of Acacia Auriculiformis A. Cunn Food Chem Toxicol. 2007:45(7):1216-23.

44. Hochstein P, Atallah A. The nature of oxidants and antioxidant systems in the inhibition of mutation and cancer. Mutat Res Fundam Mol Mech Mutagen. 1988;202(2):363-75. 
45. Gülçin I, Oktay M, Küfrevioğlu Ö, Aslan A. Determination of antioxidant activity of Lichen Cetraria Islandica (L) ach. J Ethnopharmacol. 2002;79(3): 325-9.

46. Khan R, Khan M, Sahreen S, Ahmed M. Assessment of flavonoids contents and in vitro antioxidant activity of Launaea Procumbens. Chem Cent J. 2012; 6(1):43.

47. Chew Y-L, Goh J-K, Lim Y-Y. Assessment of in vitro antioxidant capacity and polyphenolic composition of selected medicinal herbs from Leguminosae family in Peninsular Malaysia. Food Chem. 2009;116(1):13-8.

48. Manian R, Anusuya N, Siddhuraju P, Manian S. The antioxidant activity and free radical scavenging potential of two different solvent extracts of Camellia Sinensis (L.) O. Kuntz, Ficus Bengalensis L. and Ficus Racemosa L. Food Chem. 2008;107(3):1000-7.

49. Kartal N, Sokmen M, Tepe B, Daferera D, Polissiou M, Sokmen A. Investigation of the antioxidant properties of Ferula Orientalis L. using a suitable extraction procedure. Food Chem. 2007;100(2):584-9.

50. Barros L, Ferreira M-J, Queiros B, Ferreira I, Baptista P. Total phenols, ascorbic acid, B-Carotene and lycopene in Portuguese wild edible mushrooms and their antioxidant activities. Food Chem. 2007;103(2):413-9.

51. Khan R, Khan M, Sahreen S, Ahmed M. Evaluation of phenolic contents and antioxidant activity of various solvent extracts of Sonchus Asper (L.) hill. Chem Cent J. 2012:6(12):1-7.

52. Sharififar F, Dehghn-Nudeh G, Mirtajaldini M. Major flavonoids with antioxidant activity from Teucrium Polium L. Food Chem. 2009;112(4):885-8.

53. Tung $Y-T, W u ~ J-H, ~ H s i e h ~ C-Y, C h e n ~ P-S, C h a n g ~ S-T$. Free radical-scavenging phytochemicals of hot water extracts of Acacia Confusa leaves detected by an on-line screening method. Food Chem. 2009;115(3):1019-24.

54. Fejes S, Blázovics A, Lugasi A, Lemberkovics É, Petri G, Kéry Á. In vitro antioxidant activity of Anthriscus Cerefolium L. (Hoffm.) extracts. J Ethnopharmacol. 2000;69(3):259-65.

55. Ebrahimzadeh $M$, Nabavi S, Nabavi S. Antioxidant activities of methanol extract of Sambucus Ebulus L. Flower Pak J Biol Sci. 2009;12(5):447.

56. Hamidi $M$, Tajerzadeh H. Carrier erythrocytes: an overview. Drug Deliv. 2003;10(1):9-20.

57. Naim M, Gestetner B, Bondi A, Birk Y. Antioxidative and antihemolytic activities of soybean isoflavones. J Agric Food Chem. 1976;24(6):1174-7.

58. Kalaivani T, Rajasekaran C, Suthindhiran K, Mathew L. Free radical scavenging, cytotoxic and hemolytic activities from leaves of Acacia Nilotica (L.) Wild. Ex. Delile Subsp. Indica (Benth.) Brenan. Evid Based Complement Alternat Med. 2011;2011.

59. Sghaier M, Skandrani I, Nasr N, Franca M-G, Chekir-Ghedira L, Ghedira K Flavonoids and sesquiterpenes from Tecurium Ramosissimum promote antiproliferation of human cancer cells and enhance antioxidant activity: a structure-activity relationship study. Environ Toxicol Pharmacol. 2011;32(3): $336-48$

60. Li N, Liu J-H, Zhang J, Yu B-Y. Comparative evaluation of cytotoxicity and antioxidative activity of 20 flavonoids. J Agric Food Chem. 2008;56(10): 3876-83.

61. Sak K. Cytotoxicity of dietary flavonoids on different human cancer types. Pharmacogn Rev. 2014:8(16):122.

62. Obrenovich M, Nair N, Beyaz A, Aliev G, Reddy V. The role of polyphenolic antioxidants in health, disease, and aging. Rejuvenation Res. 2010;13(6): 631-43.

63. Ali A, Akhtar N, Khan B, Khan M, Rasul A, Zaman S, Khalid N, Waseem K, Mahmood T, Ali L. Acacia Nilotica: a plant of multipurpose medicinal uses. J Med Plant Res. 2012;6:1492-6.

64. Gaascht F, Dicato M, Diederich M. Venus Flytrap (Dionaea Muscipula Solander Ex Ellis) contains powerful compounds that prevent and cure cancer. Front Oncol 2013:3.

\section{Submit your next manuscript to BioMed Central and we will help you at every step:}

- We accept pre-submission inquiries

- Our selector tool helps you to find the most relevant journal

- We provide round the clock customer support

- Convenient online submission

- Thorough peer review

- Inclusion in PubMed and all major indexing services

- Maximum visibility for your research

Submit your manuscript at www.biomedcentral.com/submit

) Biomed Central 